\title{
CSR Lessons from Vedan Deeds
}

\author{
Luu Trong Tuan \\ Ho Chi Minh City University for Natural Resources and Environment \\ E-mail: luutrongtuan@vnn.vn
}

Received: September 8, 2011 Accepted: September 22, 2011 doi:10.5296/ber.v1i1.934

\begin{abstract}
Corporate social responsibility (CSR) policy functions as a built-in, self-regulating mechanism whereby business monitors and ensures its active compliance with the spirit of the law, ethical standards, and international norms. The concept of CSR has yet seemed to reach the businesses in emerging markets. Many firms are still exploiting these cheap labor markets with sweatshops, shady businesses and unethical conducts, with the most prominent example be Vedan Vietnam's pollution of Thi Vai River, destroying the trust of local governments and people.
\end{abstract}

Keywords: Corporate social responsibility (CSR), Stakeholder, Environmental sustainability, Vietnam 


\section{Introduction}

Corporate social responsibility (CSR, also called corporate conscience, corporate citizenship, social performance, or sustainable responsible business) is a form of corporate self-regulation integrated into a business model. CSR policy functions as a built-in, self-regulating mechanism whereby business monitors and ensures its active compliance with the spirit of the law, ethical standards, and international norms. The goal of CSR is to embrace responsibility for the company's actions and encourage a positive impact through its activities on the environment, consumers, employees, communities, stakeholders and all other members of the public sphere. Furthermore, CSR-focused businesses would proactively promote the public interest (PI) by encouraging community growth and development, and voluntarily eliminating practices that harm the public sphere, regardless of legality. CSR is the deliberate inclusion of PI into corporate decision-making that is the core business of the company or firm, and the honoring of a triple bottom line: people, planet, profit.

The term "corporate social responsibility" came in to common use in the late 1960s and early 1970s, after many multinational corporations formed. The term stakeholder, meaning those on whom an organization's activities have an impact, was used to describe corporate owners beyond shareholders as a result of an influential book by R. Edward Freeman, Strategic management: a stakeholder approach in 1984. Proponents argue that corporations make more long term profits by operating with a perspective, while critics argue that CSR distracts from the economic role of businesses. Others argue CSR is merely window-dressing, or an attempt to pre-empt the role of governments as a watchdog over powerful multinational corporations.

CSR is titled to aid an organization's mission as well as a guide to what the company stands for and will uphold to its consumers. Development business ethics is one of the forms of applied ethics that examines ethical principles and moral or ethical problems that can arise in a business environment. ISO 26000 is the recognized international standard for CSR (currently a Draft International Standard). Public sector organizations (the United Nations for example) adhere to the triple bottom line (TBL). It is widely accepted that CSR adheres to similar principles but with no formal act of legislation. The UN has developed the Principles for Responsible Investment as guidelines for investing entities.

\section{Overview of CSR}

In recent years the business strategy field has experienced the renaissance of corporate social responsibility (CSR) as a major topic of interest. The concept has not surfaced for the first time. CSR had already known considerable interest in the 1960s and 70s, spawning a broad range of scholarly contributions (Cheit, 1964; Heald, 1970; Ackermann and Bauer, 1976; Carroll, 1979), and a veritable industry of social auditors and consultants. However, the topic all but vanished from most managers' minds in the 1980s (Dierkes and Antal, 1986; Vogel, 1986). Having blossomed in the 1970s CSR all but vanished and only re-emerged in recent years. 
Some commentators have identified a difference between the Continental European and the Anglo-Saxon approaches to CSR. And even within Europe the discussion about CSR is very heterogeneous.

An approach for CSR that is becoming more widely accepted is a community-based development approach. In this approach, corporations work with local communities to better themselves. For example, the Shell Foundation's involvement in the Flower Valley, South Africa. In Flower Valley they set up an Early Learning Centre to help educate the community's children as well as develop new skills for the adults. Marks and Spencer is also active in this community through the building of a trade network with the community guaranteeing regular fair trade purchases. Often activities companies participate in are establishing education facilities for adults and HIV/AIDS education programmers. The majority of these CSR projects are established in Africa. JIDF For You is an attempt to promote these activities in India.

A more common approach of CSR is philanthropy. This includes monetary donations and aid given to local organizations and impoverished communities in developing countries. Some organizations do not like this approach as it does not help build on the skills of the local people, whereas community-based development generally leads to more sustainable development.

Another approach to CSR is to incorporate the CSR strategy directly into the business strategy of an organization. For instance, procurement of Fair Trade tea and coffee has been adopted by various businesses including KPMG. Its CSR manager commented, "Fair-trade fits very strongly into our commitment to our communities."

Another approach is garnering increasing corporate responsibility interest. This is called Creating Shared Value, or CSV. The shared value model is based on the idea that corporate success and social welfare are interdependent. A business needs a healthy, educated workforce, sustainable resources and adept government to compete effectively. For society to thrive, profitable and competitive businesses must be developed and supported to create income, wealth, tax revenues, and opportunities for philanthropy. CSV received global attention in the Harvard Business Review article Strategy \& Society: The Link between Competitive Advantage and Corporate Social Responsibility by Michael E. Porter, a leading authority on competitive strategy and head of the Institute for Strategy and Competitiveness at Harvard Business School; and Mark R. Kramer, Senior Fellow at the Kennedy School at Harvard University and co-founder of FSG Social Impact Advisors. The article provides insights and relevant examples of companies that have developed deep linkages between their business strategies and corporate social responsibility. Many approaches to CSR pit businesses against society, emphasizing the costs and limitations of compliance with externally imposed social and environmental standards. CSV acknowledges trade-offs between short-term profitability and social or environmental goals, but focuses more on the opportunities for competitive advantage from building a social value proposition into corporate strategy. 
Many companies use the strategy of benchmarking to compete within their respective industries in CSR policy, implementation, and effectiveness. Benchmarking involves reviewing competitor CSR initiatives, as well as measuring and evaluating the impact that those policies have on society and the environment, and how customers perceive competitor CSR strategy. After a comprehensive study of competitor strategy and an internal policy review performed, a comparison can be drawn and a strategy developed for competition with CSR initiatives.

In spite of extensive research on corporate social responsibility and its link with economic and social performance, few studies have investigated the institutional determinants of CSR. In their research, Jackson and Apostolakou (2010) draw upon neo-institutional theory and comparative institutional analysis to compare the influence of different institutional environments on CSR policies of European firms. On the basis of a dataset of European firms, these researchers find that firms from the more liberal market economies of the Anglo-Saxon countries score higher on most dimensions of CSR than firms in the more coordinated market economies (CMEs) in Continental Europe. This result lends support to the view of voluntary CSR practices in liberal economies as being a substitute for institutionalized forms of stakeholder participation. Meanwhile, CSR tends not to mirror more institutionalized forms of stakeholder coordination. Instead, in CMEs, CSR often takes on more implicit forms.

Corporate Social Responsibility aims to better integrate social and environmental concerns into business routines on a voluntary basis. Steurer's (2010) study is concerned with the political side of the management approach. By systematically characterising the public policies on CSR throughout Europe, it first complements the existing, often unsystematic, accounts of how governments address CSR (mostly provided in management journals). Second, it also brings the issue closer to political science. After explaining why governments show interest in CSR, the study introduces CSR as a voluntary contribution to sustainable development. It then develops a typology of CSR policies that distinguishes five types of policy instruments (legal, economic, informational, partnering and hybrid) and four thematic fields of action (raise awareness, improve transparency, foster socially responsible investment and lead by example). Based on this systematic description of CSR policies, the study explores what CSR and the respective public policies imply for business-government relations as well as the changing patterns of regulation. It concludes that CSR started out as a neo-liberal concept that helped to downscale government regulations, but that it has in turn matured into a more progressive approach of societal co-regulation in recent years.

Frederiksen's (2010) empirical research, furthermore, examines the relation between policies concerning Corporate Social Responsibility and philosophical moral theories. The objective is to determine which moral theories form the basis for CSR policies. Are they based on ethical egoism, libertarianism, utilitarianism or some kind of common-sense morality? In order to address this issue, Frederiksen (2010) conducted an empirical investigation examining the relation between moral theories and CSR policies, in companies engaged in CSR. The investigation concludes that CSR policies are not based on utilitarian thinking, but instead, on some kind of common-sense morality. The ethical foundation of companies engaged in CSR, thus, does not mirror the ethical foundation of managers. 


\section{CSR in Vietnam}

In Vietnam, the government has to raise the awareness of businesses and stakeholders on CSR, CSR is regarded as an important content in the agenda of sustainable development. The international development organizations in Vietnam have so much effort in promoting and implementing CSR. The programs and projects related to CSR focuses on some important issues of CSR depends on the project's objectives, resources and experience available.

The contents include: working conditions, occupational health and safety, environmental, quality and productivity, labor relations and human resource management. Consulting services and certification to management system is developed and expanded, such as quality management system (ISO9000), environmental management system (ISO14000), Labor and social responsibility Assembly (SA8000) ...

However there are some obstacles in the implementation of CSR in Vietnam as a new concept of CSR is still a lot of business for the business community in Vietnam, while the parties do not have long-term plan and strategies to implement CSR programs. Management capacity and expertise in implementing CSR in business is limited.

With growing economies of Vietnam, the majority of businesses in small and medium-scale adoption and implementation of social responsibility of enterprises has not been focused and interested.

However, some enterprises have put CSR into their business strategy. Typically, social programs such as '6 million cups of milk for children Vietnam 'and scholarship' fireflies light 'of the big brands like Vinamilk, Dutch Lady resonate and consumer support.

HUB Cafe is one of the businesses are small and medium-scale implementation of CSR by creating a community library with more than 10,000 books for customers. HUB Cafe is being built as a place to share knowledge and materials useful to students and researchers, organized the sessions and workshops on issues of education, work experience and vocational industry.

According to Truong Giang, director of the HUB Café share, initially, to build community libraries faced many difficulties. Because resources are scarce or outdated, so he and his colleagues have gathered all of his books and links to publishers Knowledge to support a rich source book. However, when the library community is formed, the level of customer care is not really desired by the reading culture in Vietnam has not developed, let alone it's a cafe, where customers like to gather and 'eight' rather than read.

Kirin also Acecook - Latte Beverage Company, a joint venture between Vietnam and Japan to implement CSR in a different way. Mr. Yokomizo Munechika, CEO of the company that strategic CSR in Vietnam Kirin Acecook will "focus on maximum quality. We are the pioneer in Vietnam applying aseptic Aseptic Filling technology, process design and bottle blowing was conducted at the factory to ensure the hygiene and the origin of the bottle." 


\section{Findings}

\subsection{Thi Vai river incident - The deeds of Vedan during many years}

Vedan (Vietnam) Enterprise Corp. Ltd is a MSG (monosodium glutamate) plant. It was established in 1991, located in Phuoc Thai Village, Long Thanh District of Dong Nai Province - about 70 kilometers southeast of Ho Chi Minh City.

The plant was built next to Thi Vai River; therefore its waste water treatment had great influence on Thi Vai. Nguyen Thanh Hung, an expert from the Natural Resources and Environment Institute of the Ho Chi Minh City National University, said the river began to be polluted in 1994 right after Vedan started its operations. In 1995 the river water began to change its color and emanate a disgusting smell. Moreover, shrimps and fish raised by farmers were decimated, all ostensibly due to the pollution. By the end of that year Vedan had to pay a compensation of VND1.8 billion (US\$107,000 at today's exchange rates) to the farmers. However, the pollution after that continued up to 13/9/2008 when Vedan was caught in the act of dumping untreated sewage into Thi Vai River. That heavily polluted this river, caused immense damage to the residents living near this river.

Investigations by Dong Nai environmental authorities and inspectors from several departments quickly revealed the practice had been going on for the previous 14 years. At first, the Ministry and the Environment Police Department said the company had discharged 45,000cu.m of post-fermentation molasses waste into the river every month. However, after discovering that the firm had built a sub-merged pipeline to discharge effluent into the river the estimate was markedly raised.

On September 29th 2009, the Ministry of Natural Resources and Environment announced that Vedan dumped nearly 110,000cu.m of untreated wastewater every month into the Thi Vai River - 2.5 times higher than earlier findings. To avoid detection, the company stored the post-fermentation molasses waste from monosodium glutamate and lysine factories into a $7,000 \mathrm{cu} . \mathrm{m}$ container unit. A second container of $15,000 \mathrm{cu} . \mathrm{m}$ and some other smaller containers of $1,500 \mathrm{cu} . \mathrm{m}$ were also buried. The containers were connected by a system of pipelines and the waste pumped into the middle of the river some eight meters below the surface.

The toxic water killed local farmers' fish and shrimp and ruined farmland along the banks of the river for a long time.

\subsection{The consequences}

Ministry officials said water quality tests found that pigment levels in the Thi Vai River were 3,675 times higher than permitted levels, while COD levels (Chemical Oxygen Demand levels) were 2,957 times, BOD5 levels (Biochemical oxygen demand levels) 1,057 times higher, and TSS (Toxic shock syndrome//chat ran lo lung - total suspended solids) and ammonia more than 100 times higher.

Scientists from the Vietnam Environment Administration Institute in Hanoi did a research using Mike 21, one of the most modern data assessment models, has found that Vedan 
contributed 89.2 percent to the pollution of the Thi Vai River. The resulting pollution has had negative impacts of different extents on a large natural area of 240 square kilometers.

\subsubsection{Effects on local residents' health}

First of all, the Thi Vai pollution brought out serious influence on local residents' health. Contamination of groundwater by Vedan's effluents leaded to pollution in soil, air and water of surrounding area throughout 14 years. The pollution has even contaminated underground water while many wells in the area are foul and unusable. A local resident in Phuoc Binh Commune, Tran Thi Son, said that the water has a bad odor and color; he cannot find fresh water any more although he had drilled other new wells because all of them were foul. It directly caused the ill-effects on the local residents' health such as skin rashes, respiratory diseases and headaches. These consequences not only happen in several years, within several people; they last a long time and affect from this generation to the next ones. Since it is difficult to recover the pure environment of Thi Vai River area like before Vedan's actions.

\subsubsection{Effects on farmland}

Secondly, the next consequence from pollution in Thi Vai River is negative effects on farmland. The pollution has caused huge losses to the farmers who depend on fishing, breeding aquatic creatures, and building dams for their livelihood. According to Natural Resources and Environment Institute, it has impacted on 2,465 hectares of fish and shrimp ponds in Dong Nai, Ba Ria-Vung Tau and Ho Chi Minh City. Nguyen Van Hung, a shrimp farmer in Phuoc Binh Commune said he had to invest VND20 million (US\$1,200) per shrimp season last year to process the polluted water, but all the shrimp in three seasons still died, at a loss of VND250 million (\%15,200). The pollution continued means killing more aquatic creatures and leading farmers to the brink of bankruptcy. As a result, the number of household involved in aquaculture also falls dramatically from 500 households to just 170 remain now, Nguyen Van Phung, Deputy Chairman of the HCMC Farmers' Association said. In addition, land for cultivation also suffered serious effects. The pollution caused a decrease in productivity as well as quality of agricultural products plants in this area.

\subsubsection{Effects on Thi Vai itself}

Last but not least, the pollution in Thi Vai River has leaded to long term consequences for the river itself. The pollution have killed aquatic creature living in Thi Vai. Since toxins in the river climb the food chain after small fish consume food, then large fish eat smaller fish, etc. Each successful step expands food net and spreads out negative impacts from pollution of Thi Vai River. Moreover, Pollution in Thi Vai River has also caused losses to enterprises as cargo ships have refused to dock at Go Dau Port. Some Singaporean and Japanese cargo ships said they wouldn't dock at the port, because the pollution would corrode their hulls. Vice General Director of Dong Nai Port JSC Pham Van Quyen said, "Singaporean cargo ships account for 200 out of the 600 ships docking at the port every year. If the situation isn't improved, more enterprises will suffer". Besides, many Japanese cargo ships also refused to transport fertilizer and raw materials for the Vietnam Japan Fertilizer Company in Go Dau Industrial Zone, Shinya Kajita - General Director of this company said. That means pollution has 
serious effects on waterway transport functions of Thi Vai - main functions of a river - and caused large financial damages for farmers and entrepreneurs.

It can be seen that groundwater pollution as in Thi Vai River is much more difficult to abate than surface pollution because groundwater can move great distances through unseen aquifers. Most water pollutants cannot stagnate in Thi Vai forever; they are eventually carried from the rivers into the oceans. Therefore, its negative effects are not only as above, they may spread lager and lager, and be unable to compute all damages. Although Vedan agrees to compensate billion dollars, it cannot make up for these losses.

\subsection{Reasons behind Vedan deeds}

\subsubsection{The main reason: to cut down the cost of waste-processing}

Sewage treatment is the process of removing contaminants from wastewater. It includes physical, chemical, and biological processes to remove physical, chemical and biological contaminants. Conventional sewage treatment may involve three stages, called primary, secondary and tertiary treatment.

- $\quad$ Primary treatment consists of temporarily holding the sewage in a quiescent basin where heavy solids can settle to the bottom while oil, grease and lighter solids float to the surface. The settled and floating materials are removed and the remaining liquid may be discharged or subjected to secondary treatment. In this stage, it may remove from 60 to 65 percent of suspended solids, and from 30 to 35 percent of biochemical oxygen demand (BOD) from the sewage.

- $\quad$ Secondary treatment removes dissolved and suspended biological matter. Secondary treatment is typically performed by indigenous, water-borne micro-organisms in a managed habitat. Secondary treatment may require a separation process to remove the micro-organisms from the treated water. The final step in the secondary treatment stage is to settle out the filter material through a secondary clarifier and to produce sewage water containing low levels of organic material and suspended matter.

- $\quad$ Tertiary treatment is sometimes defined as anything more than primary and secondary treatment. Treated water is sometimes disinfected chemically or physically (for example, by lagoons and microfiltration) prior to discharge into a stream, river, bay, lagoon or wetland, or it can be used for the irrigation of a golf course, green way or park. If it is sufficiently clean, it can also be used for groundwater recharge or agricultural purposes.

Especially, industrial sources of wastewater as in Vedan often require specialized treatment processes. The different types of contamination of wastewater require a variety of strategies to remove the contamination such as solids removal, oils and grease removal, removal of biodegradable organics, treatment of other organics, treatment of acids and alkalis, treatment of toxic materials. It can be seen that the industrial wastewater treatment process is very complicated and requires high cost which is estimated about 31 million USD $=589$ billion VND. 


\subsubsection{Low corporate ethics}

Vedan did not have a clear sense of its responsibility in discharging pollution. Its General Director Yan Kun Hsiang said his company did not agree with the finding that it caused more than 89 percent of the pollution. He argued that Vedan was not the only polluter because many other companies had also discharged wastewater into the river. However, with obvious evidences and persuasive accusations, Vedan finally admitted it had polluted the main part of the Thi Vai River, a stretch of about 10 kilometers, but still rejected the conclusion that it caused more than 89 percent of the pollution.

In September 2009, Vedan had rejected a compensation request of VND569 billion (\$31.7 million) as financial support to farmers affected by the pollution. Even though this amount of money represented 50 percent less than the initial demand of VND1.2 trillion (\$67.4 million) made by farmers from three affected localities, the company said it needed more evidence from the authorities and that the sum was too large.

Besides arguments about the compensations for farmers, Vedan keeps not much goodwill in dealing with compensation. They even prolonged the case and gave invalid reasons to bargain the compensation amount. This amount changed from VND7 billion to VND15 billion and then VND30 billion in Dong Nai province; from VND6 billion to VND10 billion in Ba Ria Vung Tau; and from VND7 billion to VND12 billion, then up to VND16 billion. Meanwhile, the actual damages in these three regions are VND119 billion, VND53 billion, and VND45 billion, respectively. It can be seen that Vedan expressed low society responsibilities for its wrong actions.

\subsection{The effects of Vedan deeds on itself}

\subsubsection{Reactions from external stakeholders}

\section{- $\quad$ From the government as a stakeholder}

The Government chief asked the authority of the southern province of Đồng Nai to cooperate with the Ministry of Natural Resources and Environment (MONRE) and the Ministry of Public Security to strictly implement two MONRE-made decisions, namely Decision 1999/QĐ-BTNMT on October 6, 2008 on suspending Vedan's license to discharge its sewage into water sources and Decision 131/QĐ-XPHC on the same day to impose administrative penalty against Vedan's law infringement.

The prime minister required Đồng Nai's People's Committee to closely supervise Vedan's observation of the two decisions. He ordered Ministry of Natural Resources and Environment and the Đồng Nai People's Committee to seriously consider their lack of close coordination and unanimity in managing Vedan's operations as well as in dealing with the company's violations. They were forced to make report to the PM in November 2008.

\section{- $\quad$ From residents}

The three associations from Ho Chi Minh City, Dong Nai and Ba RiaVung Tau provinces said they had received nearly 10,920 letters demanding legal action against Vedan. Especially, 
in Ba Ria-Vung Tau Province, 1,094 out of 1,255 affected farmers have completed procedures to file a lawsuit against Vedan, and the others are being concluded.

There are many public opinions about this urgent matter. Tran Van Cuong, Deputy Director of the province's department of agriculture and rural development said on Tuoi Tre (Youth) newspaper: "We're determined to send the Vedan case to court, and we must complete lawsuit procedures before the September deadline". If the Dong Nai Association has no funds for court charges, the local authorities should lend farmers money, or the association should call for assistance from the community. A farmer in Dong Nai Province, Nguyen Lam Son even said he would sue Vedan on his own. He has received free advice from a lawyer at the HCM City Bar Association.

Many people feel dissatisfied with Vedan, and are ready to help farmers sue this MSG plant. They claim that the Vedan Viet Nam Joint-stock Company Ltd.'s violations of environment protection laws must be punished resolutely, thoroughly and strictly through proper steps to put an end to the illegal discharge of untreated sewage, overcome consequences, maintain production activities, and protect legitimate interests of the company's employees.

\subsubsection{Financial damages}

\section{- $\quad$ Fine and environmental fees}

The Ministry of Natural Resources and Environment suspended the plant's wastewater discharge license and fined the company VND267.5 million (current US\$15,030) in November 2008. The Ministry also demanded VND127 billion (current \$7.14 million) from the company in overdue environmental fees. The company has paid the first fine and agreed to pay the fees in three installments.

\section{- $\quad$ Compensation}

The Ho Chi Minh City Farmers' Association asked Vedan Vietnam for VND569 billion (\$31.970 million) as financial support to farmers who are affected from the Thi Vai River pollution.

\section{- $\quad$ Cost of restoring Thi Vai River}

The Ministry said Vedan would have to pay the cost of restoring the river, which is now devoid of life. They have to construct a sewage treatment system in order to minimize the environment pollution.

\section{- $\quad$ Decline in revenue}

With Thi Vai River case, Vedan's operations were interrupted for a time. There are about 10,920 letters demanding against Vedan from citizen. They do not trust Vedan as before. Besides, some grocery stores and markets even boycotted all Vedan products. These bad reactions from customers leaded to a significant fall in both Vedan revenue and reputation. 


\section{Lessons in conduct}

From the case of Vedan, we may recognize that the success in CSR needs many factors; in which the two basic are awareness and conduct. The lesson in awareness and attitude is the need to help build a sustainable society and environment and the risk of not doing it. Learn about Walt Disney, one of the most successful companies with CSR, you can take a lesson of the way how CSR's conduct must be. Moreover, through the cases, you also see the link between good CSR policy and increasing reputations and benefits of company itself.

\subsection{Realizing the importance of building a sustainable society and pure environment}

Sustainability means achieving satisfying lives for all within the means of nature - now and in the future. A sustainable society provides opportunities for each member of the community to reach his/her potential; it provides strength and resilience to the human community, provides access to work, play, health care, education and so on, for each of its members. Moreover, a sustainable society also resolves the inherent conflicts among its members through peaceful, respectful and non-violent means. In the other word, a sustainable society provides a high quality of life for all of its inhabitants without harming the integrity and productivity of the natural systems and resources upon which all life depends. It can be seen that sustainability for a society in general is very important; it is likely a goal of human being.

Environment is one of essential parts of a sustainable society, and also a concerned problem in many regions. People depend on the nature's capacity to take food, water, energy, fiber, and life-support services such as the pollination of crops and creation of soils. Besides, people also depend on its capacity to detoxify their waste. Therefore, saving natural resources and protecting the environment are also considered as necessary strategies for sustainable living.

Communities including all individuals, groups, organizations, etc. each one needs to have a deep sense of taking responsibility in building a sustainable society. CSR plays an important role in reaching this goal. A sustainable society cannot arise with ignorance, irrationality or greed. The basic principle in creating a sustainable living is possessing high corporate ethics. It reflects the duty of care for the community life and other forms of life, now and in the future. All life on earth is a part of one great interdependent system; thus, any disturbing one part of this biosphere can affect the whole. In order to improve quality of life but still does not threaten the survival of other species or eliminate their habitats, human being may together minimize the depletion of non-renewable resources; conserve the earth's vitality such as soil, water, air; and conserve biodiversity comprising all species of plants, animals and other organisms. All societies need a foundation of information and knowledge, and then together build a national framework for integrating development and conservation. Step by step, all nations are directed toward a global alliance to achieve global sustainability.

\subsection{Realizing the link between good CSR policy and increasing profit}

A business operation doesn't exist in a simply way of making money. It is put in a close relationship of customers, suppliers and the local community. Any actions of its operation products, and the ways to make them - have a direct impact on the environment. Corporate 
social responsibility (CSR) is known as understandings about that impact on the wider world and considering how can use this impact in a positive way. Many successful firms such as Walt Disney, Toshiba Group, etc, found a correlation between social/environmental performance and financial performance. CSR events are hold to express the importance of CSR and raise CSR awareness of employees. Actually, businesses may not be looking at short-run financial returns when developing their CSR strategy, they should look at potential benefits which help their business go smoothly and increase stably profit in long-run.

First of all, firms can attract more talent from recruitment through their high CSR. In fact, in an interview, potential recruits usually ask about the firm's CSR policy. Having comprehensive responsibility about the society as well as about staffs will make them put their faith in the firm. Moreover, that working environment also gives employees something to proud. As a result, they may want to work and devote to the company. This is one important element to make valuable products which create high profit in long run.

Secondly, many branches sell luxury or unique products, this is a good way to attract customers. Besides, having high CSR is considered an effective way to polish reputation of the firm and build loyalty from customers. Together with development of the society, CSR is appreciated. It is easy to understand when a firm causes damages to society; customers are ready to boycott that branch such as Vedan. Inversely, when the firm shows government and the public that they do take care of social issues such as health, environment, labor life...etc., customers like and trust that branch. It is clear that CSR of the firm also has impact of market outlet as well as revenue of the company.

Another link between CSR and profit is risk management capacity. Reputations that take decades to build up can be ruined in hours through incidents such as corruption scandals or environmental accidents. Vedan is an obvious example of this situation. Being popularly known as a famous branch with supplying MSG through many years in many countries, Vedan deteriorated its branch name after Thi Vai River incident. If Vedan takes its responsibility right the year of starting its operation in Vietnam, it did not cause serious consequences and losses its reputation. With high CSR, the firm can avoid unwanted risks regulators, courts, governments and media; avoid compensations for their irresponsible actions. From that, the firms not only save money, but also operate their business continuously.

\section{Concluding remarks}

Although the concept of Corporate Social Responsibility has been around since the 1980s, it's only in the recent wave of globalization, mass consumer awareness and public accountability that companies have realized the need to adopt ethical policies. As companies become more accountable not only for their own actions but for those within their supply chain, they have to adapt to ensure success within not only themselves but also the context of the global society they operate in.

However, not every business has the financial ability and, more importantly, morality to pursue the good cause. While large corporations such as Walt Disney, Google or Timberland 
have shown their considerable contribution to the community in all aspects: saving the environment, preventing climate change and improving the living standard with their triple bottom line; others are still looking for more profit in any way possible, harming the society in the process.

Furthermore, the concept of CSR has yet seemed to reach the businesses in emerging markets. Many firms are still exploiting these cheap labor markets with sweatshops, shady businesses and unethical conducts, with the most prominent example be Vedan Vietnam's pollution of Thi Vai River, destroying the trust of local governments and people.

Nevertheless, we are looking at a brighter future with the transformation of business ethics standards into CSR 2.0. A more intelligent, evolved form of CSR - rebranded as Corporate Sustainability \& Responsibility - CSR 2.0 uses the power of collaborative networks to scale up solutions to our global challenges. Based on four principles: connectivity, scalability, responsiveness and paradoxy, CSR 2.0 describes how the concept and practice of corporate social responsibility (CSR) is on the edge of a revolution, in much the same way as the internet transitioned from Web 1.0 to Web 2.0. The transformation of the internet through the emergence of social media networks, user-generated content and open source approaches is a metaphor for the changes business is experiencing as it begins to redefine its role in society.

With a new channel to communicate, a new tool to promote good deeds, and many motivations, let us hope that businesses are learning that they can do well, by doing good.

\section{References}

Ackermann, R., \& Bauer, R. (1976). Corporate Social Performance: The Modern Dilemma. Reston: Reston Publishing Co.

Carroll, A. (1979). A Three-Dimensional Conceptual Model of Corporate Performance. Academy of Management Review, 4: 497-505.

Cheit, E.F. (1964). Why Managers Cultivate Social Responsibility. California Management Review, 7: 3-22.

Dierkes, M., \& Antal, A.B. (1986). Whither Corporate Social Reporting: Is It Time to Legislate? California Management Review, 28: 106-121.

Frederiksen, C.S. (2010). The Relation Between Policies Concerning Corporate Social Responsibility (CSR) and Philosophical Moral Theories - An Empirical Investigation. Journal of Business Ethics, Vol. 93 No. 3, pp. 357-371. http://dx.doi.org/10.1007/s10551-009-0226-6

Heald, M. (1970). The Social Responsibilities of Business: Company and Community, 1900-1960. Cleveland: Case Western Reserve University Press.

Jackson, G., and Apostolakou, A. (2010). Corporate Social Responsibility in Western Europe: An Institutional Mirror or Substitute? Journal of Business Ethics, Vol. 94 No. 3, pp. 371-394. 
Steurer, R. (2010). The role of governments in corporate social responsibility: characterising public policies on CSR in Europe. Policy Sciences, Vol. 43 No. 1, pp. 49-72. http://dx.doi.org/10.1007/s11077-009-9084-4

Vogel, D. (1986). The Study of Social Issues in Management: A Critical Appraisal. California Management Review, 28: 142-151. 